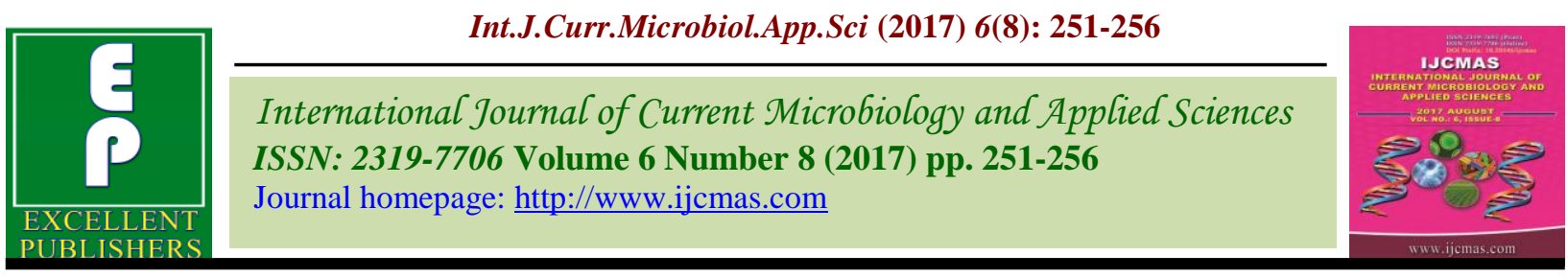

Original Research Article

https://doi.org/10.20546/ijcmas.2017.608.034

\title{
Suggestions to Overcome Constraints by the Aonla Growers
}

\author{
S. Choudhary* and I.M. Khan \\ Department of Extension Education, SKN COA, Jobner (RAJ), India \\ *Corresponding author
}

\section{A B S T R A C T}

Keywords

Agriculture information, Management, Behaviour aonla and suggestion.

\section{Article Info}

Accepted: xx June 2017 Available Online: xx August 2017
The study was conducted in Semi-Arid Eastern Plains Zone (IIIa) of Rajasthan state. In Semi-Arid Eastern Plain Zone (III a) there are 4 districts namely Ajmer, Jaipur, Dausa and Tonk. Out of these two districts namely Ajmer and Jaipur were selected for study purpose. Respondents from each village in the districts had been randomly selected by using proportionate sampling procedure, thus making a total of 240 respondents and data was collected by personal interview method. Regarding suggestion the aonla growing farmers and farm women identified "The extension system at grass root level should be strengthened" (MPS 86.02 and 85.42 respectively) as the most important suggestion of agriculture information. In both Jaipur and Ajmer districts the aonla growing farmers and farm women "The extension system at grass root level should be strengthened" (MPS 85.40 and 85.00 respectively in Jaipur district and MPS 86.67 and 85.83 respectively in Ajmer district) was perceived as the most important suggestion of agriculture information. It was also found that there was a highly significant difference between the aonla growing farmers and farm women with respect to their suggestion of agriculture information.

\section{Introduction}

An improvement and strengthening of agricultural infrastructure needed to all the levels of supply chain. Shrinking extension is another component of infrastructure that needs attention. After the green revolution in the mid-sixties there has been no major technological innovation, which could give a fresh impetus to agricultural productivity, insufficient extension services and poor access to information further widen the gap in the adoption of technology and lead to poor productivity levels. A push towards higher productivity will require information based, decision making agricultural system. This is often described as the next great evolutionary step in agricultural. Today's farmers desire not only the meals for their families from their hard sweat but also surplus production which can sold in the market to get sufficient money to fulfill the daily requirements. According to economic reforms in the country each and every sector has changed its strategies in view of global competition.

\section{Materials and Methods}

The study was conducted in Semi-Arid Eastern Plains Zone (IIIa) of Rajasthan state. In Semi-Arid Eastern Plain Zone (IIIa) there are 4 districts namely Ajmer, Jaipur, Dausa and Tonk. Out of these two districts namely Ajmer and Jaipur were selected for study 
purpose. The study was conducted in 30 villages of six tehsils namely, Ajmer and Kishangarh of Ajmer district and Chomu, Amber, Jhotwara and Shahpura tehsils of Jaipur district. From each selected village 4 aonla growing farmers and 4 aonla growing farm women were selected randomly by simple random sampling. In this way a total of 40 aonla growing farmers and 40 aonla growing farm women from Ajmer district and 80 aonla growing farmers and 80 aonla growing farm women from Jaipur district were selected to constitute the total sample size of 120 aonla growing farmers and 120 aonla growing farm women comprising a total of 240 respondents for the study purpose.

\section{Results and Discussion}

The data related with suggestions to overcome constraints of agriculture information by the aonla growing farmers and farm women incorporated in table 1 shows that calculated Wilcoxen ' $Z$ ' value for the suggestion no. $1,2,3,4,5,6,7,10,11,12$, $13,14,15,16,18,19,21,23,25,26$ and 27 were more than the tabulated value at 5 per cent level of significance. Hence, the null hypothesis was rejected and alternate hypothesis was accepted, which leads to the conclusion that there is a significant difference between aonla growing farmers and farm women with respect to these suggestions to overcome constraints in agriculture information management. Whereas the calculated Wilcoxen ' $Z$ ' value for the suggestion no. 8, 9, 17, 20, 22 and 24 were less than the tabulated value at 5 per cent level of significance. Hence, the null hypothesis was accepted and alternate hypothesis was rejected, which leads to the conclusion that there is no significant difference between aonla growing farmers and farm women with respect to these suggestions to overcome constraints in agriculture information management. The data presented in Table 1. indicates that for aonla growing farmers and farm women identified "The extension system at grass root level should be strengthened" (MPS 86.04 and 85.42 respectively) first most important suggestion, whereas, the anola growing farmers identified "The extension contact between aonla growers and extension workers should be increased" (MPS 84.19) and farm women identified "The supply of newspaper/ Journals/ magazines in remote area should be increased" (MPS 83.97) second most important suggestion. However, the anola growing farmers and farm women identified "Essential equipments should be provided for organizing and conducting meetings, trainings for various activities" (MPS 57.09 and 58.75) least most important suggestion of the respondents.

In both Jaipur and Ajmer districts the aonla growing farmers and farm women identified "The extension system at grass root level should be strengthened" (MPS 85.40 and 85.00 respectively in Jaipur district and MPS 86.67 and 85.83 respectively in Ajmer district) first most important suggestion, whereas, In Jaipur district the aonla growing farmers identified "The extension contact between aonla growers and extension workers should be increased" (MPS 84.20) and farm women identified "The supply of newspaper/ Journals/ magazines in remote area should be increased" (MPS 84.60) second most important suggestion. Whereas, In Ajmer district the aonla growing farmers and farm women identified "The communication ability of extension workers should be increased" (MPS 85.00 and 84.17) second most important suggestion, however, in both Jaipur and Ajmer districts the aonla growing farmers and farm women identified. 
Table.1 Suggestion to overcome constraints by the aonla growers

$\mathrm{N}=\mathbf{2 4 0}$

\begin{tabular}{|c|c|c|c|c|c|c|c|c|c|c|c|c|c|c|}
\hline \multirow{3}{*}{ S. No. } & \multirow{3}{*}{ Suggestions } & \multicolumn{4}{|c|}{$\begin{array}{l}\text { Jaipur district } \\
(\mathrm{N}=160)\end{array}$} & \multicolumn{4}{|c|}{$\begin{array}{c}\text { Ajmer district } \\
(\mathrm{N}=\mathbf{8 0})\end{array}$} & \multicolumn{4}{|c|}{$\begin{array}{c}\text { Total respondents } \\
(\mathrm{N}=\mathbf{2 4 0})\end{array}$} & \multirow[t]{3}{*}{$\begin{array}{l}\text { Wilcoxen } \\
\text { ( } \mathrm{Z} \text { value })\end{array}$} \\
\hline & & \multicolumn{2}{|c|}{$\begin{array}{c}\begin{array}{c}\text { Farmers } \\
(\mathbf{n}=\mathbf{8 0})\end{array} \\
\end{array}$} & \multicolumn{2}{|c|}{$\begin{array}{c}\text { Farm women } \\
(\mathbf{n}=\mathbf{8 0})\end{array}$} & \multicolumn{2}{|c|}{$\begin{array}{c}\text { Farmers } \\
(\mathrm{n}=\mathbf{4 0})\end{array}$} & \multicolumn{2}{|c|}{$\begin{array}{c}\text { Farm women } \\
(\mathbf{n}=\mathbf{4 0})\end{array}$} & \multicolumn{2}{|c|}{$\begin{array}{c}\text { Farmers } \\
(\mathbf{n}=120)\end{array}$} & \multicolumn{2}{|c|}{$\begin{array}{c}\text { Farm women } \\
(\mathbf{n}=120)\end{array}$} & \\
\hline & & MPS & Rank & MPS & Rank & MPS & Rank & MPS & Rank & MPS & Rank & MPS & Rank & \\
\hline 1. & $\begin{array}{l}\text { Educational tours of the aonla } \\
\text { cultivators should be conducted in } \\
\text { potential area of aonla fruit } \\
\text { improvement, Research Centers and } \\
\text { KVKs having model demonstration } \\
\text { units to motivate and educate them } \\
\text { about latest technical know-how about } \\
\text { aonla cultivation. }\end{array}$ & 62.90 & $\mathrm{XX}$ & 68.75 & $\mathrm{XX}$ & 65.00 & XXI & 65.83 & XXII & 63.95 & XXII & 67.29 & XXII & $2.44 *$ \\
\hline 2. & $\begin{array}{l}\text { Transfer of technology programmes } \\
\text { should be implemented so effectively } \\
\text { that even illiterate farmers of remote } \\
\text { villages are also benefited. }\end{array}$ & 67.90 & $\mathrm{XV}$ & 74.60 & XIII & 72.50 & $\mathrm{XV}$ & 71.67 & XVI & 70.2 & XVI & 73.14 & XIV & $2.26^{*}$ \\
\hline 3. & $\begin{array}{l}\text { More number of aonla fruit } \\
\text { demonstrations should be laid on } \\
\text { farmer's field to popularize the high } \\
\text { yielding varieties as well as other } \\
\text { recommended technologies. }\end{array}$ & 71.7 & XI & 77.50 & IX & 77.50 & $X$ & 78.33 & VIII & 74.6 & XI & 77.92 & IX & $1.96^{*}$ \\
\hline 4 & $\begin{array}{l}\text { Experience of progressive farmers who } \\
\text { obtained higher aonla yield should be } \\
\text { documented, highlighted and they may } \\
\text { be rewarded through citation and by } \\
\text { awarding prizes. }\end{array}$ & 61.70 & XXI & 65.80 & XXII & 63.33 & XXIII & 66.67 & XXI & 62.52 & XXIII & 66.24 & XXIII & $2.52 *$ \\
\hline 5 & $\begin{array}{l}\text { Farmers should be provided training on } \\
\text { cleaning, grading, processing and value } \\
\text { addition for obtaining better prices. }\end{array}$ & 65.80 & XVIII & 71.67 & XVII & 69.20 & XVIII & 68.30 & XIX & 67.5 & XIX & 69.99 & XXI & $2.34 *$ \\
\hline 6 & $\begin{array}{l}\text { The extension system at grass root level } \\
\text { should be strengthened. }\end{array}$ & 85.40 & I & 85.00 & I & 86.67 & I & 85.83 & I & 86.04 & I & 85.42 & I & $2.28 *$ \\
\hline
\end{tabular}


\begin{tabular}{l|l}
7 & Refresher courses should be organized
\end{tabular} for field level extension functionaries to update their knowledge about changing trends and latest technology of aonla cultivation.

8 Publication and distribution of literature based on latest aonla cultivation technology among field functionaries and cultivators should be increased.

9 Strong linkages among research institutes, extension agencies and farmers should be developed for effective implementation of recommended technologies to ensure co-operation and perfect co-ordination.

10 Well-organized extension programmes should be developed for wide diffusion and quick adoption of recommended aonla cultivation technology.

11 Need based trainings should be given to the aonla growers time to time

12 Provision of incentives should be kept for field functionaries performing better.

13 Journals/ magazines should be supplied time to time at reasonable cost to the aonla growers.

14 Time should be increased for agriculture programme in T.V. and Radio.

15 Maximum programmes should be broadcasted/ telecasted at morning and evening time.

16 Agricultural programmes should be use in local language.

17 The aonla growers should be motivated for demonstrations for adopting the package of practices at their farm.

\begin{tabular}{|c|c|c|c|c|c|c|c|c|c|c|c|c|}
\hline 61.70 & XXI & 63.30 & XXIV & 61.67 & XXIV & 62.50 & XXIV & 61.69 & XXV & 62.9 & XXV & $2.75^{*}$ \\
\hline 69.20 & XIII & 72.90 & XV & 68.33 & XIX & 67.50 & XX & 68.77 & XVII & 70.2 & XX & 1.58 \\
\hline 74.58 & VIII & 79.58 & VII & 79.17 & VIII & 79.17 & VII & 76.88 & VIII & 79.38 & VII & 1.42 \\
\hline 67.10 & XVI & 73.80 & XIV & 70.00 & XVII & 69.17 & XVIII & 68.55 & XVIII & 71.49 & XVII & $2.38 *$ \\
\hline 63.80 & XIX & 71.42 & XVIII & 66.67 & XX & 70.83 & XVII & 65.24 & XXI & 71.13 & XVIII & $1.98 *$ \\
\hline 54.17 & XXIV & 60.42 & XXV & 60.67 & XXV & 63.33 & XXIII & 57.92 & XXVI & 61.88 & XXVI & $2.19 *$ \\
\hline 75.40 & VII & 78.80 & VIII & 80.00 & VII & 77.50 & IX & 77.7 & VII & 78.15 & VIII & $2.87 *$ \\
\hline 73.30 & IX & 75.80 & XI & 77.50 & $X$ & 79.67 & $X$ & 75.4 & IX & 77.74 & $X$ & $2.06 *$ \\
\hline 72.50 & $X$ & 75.00 & XII & 78.30 & IX & 73.30 & XIV & 75.4 & IX & 74.15 & XII & $2.16^{*}$ \\
\hline 68.75 & XIV & 71.67 & XVII & 73.32 & XIV & 74.17 & XIII & 71.04 & XIV & 72.92 & XV & $2.84 *$ \\
\hline 79.17 & V & 82.50 & IV & 82.50 & $\mathrm{~V}$ & 81.65 & V & 80.84 & V & 82.08 & IV & 1.86 \\
\hline
\end{tabular}




\begin{tabular}{|c|c|c|c|c|c|c|c|c|c|c|c|c|c|c|}
\hline 18 & $\begin{array}{l}\text { The space in Newspaper for agriculture } \\
\text { information should be increased. }\end{array}$ & 68.75 & XIV & 72.08 & XVI & 75.00 & XII & 75.80 & XI & 71.88 & XIII & 73.94 & XIII & $3.55^{*}$ \\
\hline 19 & $\begin{array}{l}\text { More illustrations providing technical } \\
\text { knowledge should be given in } \\
\text { Newspaper. }\end{array}$ & 66.30 & XVII & 70.42 & XVIII & 74.20 & XIII & 73.30 & XIV & 70.25 & $X V$ & 71.86 & XVI & $4.07 *$ \\
\hline 20 & $\begin{array}{l}\text { The extension contact between aonla } \\
\text { growers and extension workers should } \\
\text { be increased. }\end{array}$ & 84.20 & II & 80.30 & VI & 84.17 & III & 82.50 & IV & 84.19 & II & 81.4 & V & 1.14 \\
\hline 21 & $\begin{array}{l}\text { A well equipped agriculture } \\
\text { information center should be } \\
\text { established }\end{array}$ & 60.40 & XXII & 67.50 & XXI & 64.17 & XXII & 59.17 & XXV & 62.29 & XXIV & 63.34 & XXIV & $2.36^{*}$ \\
\hline 22 & $\begin{array}{l}\text { The knowledge about computer/ } \\
\text { internet/e-mail to the aonla growers } \\
\text { should be provided. }\end{array}$ & 70.40 & XII & 76.70 & $X$ & 76.67 & XI & 75.00 & XII & 73.54 & XII & 75.85 & XI & 1.27 \\
\hline 23 & $\begin{array}{l}\text { The supply of newspaper/ Journals/ } \\
\text { magazines in remote area should be } \\
\text { increased. }\end{array}$ & 81.30 & IV & 84.60 & II & 83.33 & IV & 83.33 & III & 82.32 & IV & 83.97 & II & $2.70^{*}$ \\
\hline 24 & $\begin{array}{l}\text { The communication ability of extension } \\
\text { workers should be increased. }\end{array}$ & 82.50 & III & 83.75 & III & 85.00 & II & 84.17 & II & 83.75 & III & 83.96 & III & 1.46 \\
\hline 25 & $\begin{array}{l}\text { The communication facilities like radio, } \\
\text { TV, telephone etc. should be provided } \\
\text { to the aonla growers. }\end{array}$ & 76.67 & VI & 81.67 & $\mathrm{~V}$ & 81.67 & VI & 80.83 & VI & 79.17 & VI & 81.25 & VI & $2.84 *$ \\
\hline 26 & $\begin{array}{l}\text { Extension workers should be given } \\
\text { more opportunities to attend training } \\
\text { programme. }\end{array}$ & 60.40 & XXII & 69.17 & XIX & 71.67 & XVI & 72.50 & $\mathrm{XV}$ & 66.04 & $X X$ & 70.84 & XIX & $2.94 *$ \\
\hline 27 & $\begin{array}{l}\text { Essential equipments should be } \\
\text { provided for organizing and conducting } \\
\text { meetings, trainings for various } \\
\text { activities. }\end{array}$ & 59.10 & XXIII & 64.17 & XXIII & 56.67 & XXVI & 53.33 & XXVI & 57.09 & $\underset{\mathrm{XXVI}}{\mathrm{I}}$ & 58.75 & $\begin{array}{l}\text { XXVI } \\
\text { I }\end{array}$ & $2.42^{*}$ \\
\hline
\end{tabular}


"Essential equipments should be provided for organizing and conducting meetings, trainings for various activities" (MPS 59.10 and 64.17 respectively in Jaipur district and MPS 56.67 and 53.33 respectively in Ajmer district) least most important suggestion of the agriculture

The findings revealed that the 'extension system at grass root level should be strengthened' was identified as the most important suggestion by all the categories of aonla growers. This might be due to the reason that majority of the extension staff were technical persons appointed by government, the extension staff works as a bridge to provide latest technology to the farmer's field and well known about farmer's situations.

In conclusion, the extension system at grass root level should be strengthened' was perceived as the most important suggestion by all the categories of aonla growers significant correlation between the aonla growing farmers and farm women was observed with respect to their suggestions to overcome the constraints in agriculture information.

\section{Recommendations}

1. It is suggested to increase the space in newspapers to cover more agricultural information. The language of agricultural information in the newspapers is simple because majority of rural information seekers are less educated. So more illustrated technical knowledge should be given to them.

2. The wide publicity of extension activities like 'exhibition', 'field days', 'kisan mela' etc. should be done well in advance before starting the activities through the media like 'radio' and 'TV' to which the aonla growers were found most exposed.

\section{References}

Dhayal, B.L., Khan, I.M. and Jangid, M.K. 2014. Constraints perceived by ber growers in seeking information on ber cultivation in Jaipur District of Rajasthan. Indian Res. J. Social Res., Vol. 55(6), pp.795-805.

Sharma, H. 2009. Managerial ability of lime growers about recommended cultivation of lime in flood prone eastern plain zone (III b) of Rajasthan, Ph.D. Thesis. SKN COA, Jobner.

Yadav, B.S. 2009. Information Seeking Behaviour of Fenugreek Growers in Jaipur Region of Rajasthan. Ph.D. Thesis, RAU, Bikaner, Campus-Jobner.

\section{How to cite this article:}

Choudhary, S. and Khan, I.M. 2017. Suggestions to Overcome Constraints by the Aonla Growers. Int.J.Curr.Microbiol.App.Sci. 6(8): 251-256. doi:

https://doi.org/10.20546/ijcmas.2017.608.034 